ECOLOGICA, Vol. 28, No 104 (2021), 494-502

https://doi.org/10.18485/ecologica.2021.28.104.2

Originalni naučni rad

UDC: $502.14(4-67 E U)$

$502.14(497)$

\title{
Zeleni dogovor Evropske unije i Zelena agenda za Zapadni Balkan: nove smernice za suočavanje sa izazovima zaštite životne sredine
}

\section{European Union Green Agreement and Green Agenda for the Western Balkans: new guidelines for tackling environmental challenges}

\author{
Zorančo Vasilkov ${ }^{1}$, Slobodan Petrović ${ }^{2}$, Jelena Vuković ${ }^{3}$, \\ Dragana Lazić ${ }^{4}$, Aleksandar Damnjanović ${ }^{*}$ \\ 1,3,4,5Poslovni i pravni fakultet, Univerzitet MB, Beograd, Srbija / \\ Faculty of Business and Law, University „MB“, Belgrade, Serbia \\ ${ }^{2}$ Fakultet društvenih nauka, Univerzitet Privredna akademija, Novi Sad, Srbija / \\ Faculty of Social Sciences, University of Business Academy, Novi Sad, Serbia \\ *Autor za prepisku / Corresponding author
}

Rad primljen / Received: 10.09.2021, Rad prihvaćen / Accepted: 04.10.2021.

\begin{abstract}
Sažetak: Evropski zeleni dogovor (European Green Deal) je danas jedna od strategija koja revidira i ambiciozno postavlja rokove za realizaciju ciljeva zaštite životne sredine u skladu sa načelom održivog razvoja. Usvajanjem strategije u decembru 2019. godine, teži se transformaciji društva unutar EU u pravedno i prosperitetno društvo sa modernom, resursno e+fikasnom i konkurentnom privredom u kojoj 2050. godine neće biti neto emisije gasova sa efektom staklene bašte i u kojem privredni rast nije povezan sa upotrebom resursa. Zelena agenda za Zapadni Balkan obuhvata smernice Komisije u okviru Ekonomskog i investicionog plana za Zapadni Balkan. Zelena agenda je nacrt mogućih mera koje moraju biti usvojene na osnovu postojećih sporazuma o stabilizaciji i pridruživanju, u okviru pregovaračkih poglavlja za pristupanje EU i programima ekonomske saradnje. Evropski zeleni dogovor i Zelena agenda za Zapadni Balkan su temeljan pregled aktuelnog stanja rizika i pretnji po životnu sredinu sa jasnim smernicama budućeg delovanja država u promeni politika, izmeni zakonodavstava $i$ jačanje svesti pojedinaca sa primerenijim i ubrzanijim vremenskim okvirom mera za zaštitu osnovnih ekoloških vrednosti. One omogućavaju da države Zapadnog Balkana zajedno sa državama članicama EU usklade svoje aktivnosti na sprečavanju budućih ekoloških katastrofa, pandemija i kriza koje proizlaze iz prekomerne eksploatacije, menjanja i uništavanja prirode u trci za materijalnim dobrima i visokim nacionalnim dohotkom, kao i nemarnog i indolentnog odnosa ljudi prema prirodi i životnoj sredini.
\end{abstract}

Kjučne reči: Evropski zeleni dogovor, Zelena agenda, zaštita životne sredine, klimatske promene, održivi razvoj.

\begin{abstract}
Today, the European Green Deal is one of the strategies that revises and ambitiously sets deadlines for the realization of environmental goals in accordance with the principle of sustainable development. With the adoption of the strategy in December 2019, the goal is to transform the society within the EU into a just and prosperous society with a modern, resource efficient and competitive economy in which there will be no net greenhouse gas emissions in 2050 and in which economic growth is not linked to resource use. The Green Agenda for the Western Balkans includes the Commission's guidelines within the Economic and Investment Plan for the Western Balkans. The Green Agenda is a draft of possible measures to be adopted on the basis of existing Stabilization and Association Agreements, within the negotiating chapters for EU accession and economic cooperation programs. The European Green Agreement and the Green Agenda for the Western Balkans are a thorough overview of the current state of risks and threats to the environment with clear guidelines for future action of states in changing policies, changing legislation and raising awareness of individuals with more appropriate and accelerated timeframe. They enable the countries of the Western Balkans, together with the EU member states, to coordinate their activities to prevent future environmental disasters, pandemics and crises resulting from overexploitation, alteration and destruction of nature in the race for material goods and high national income, as well as careless and indolent human attitude according to nature and the environment.
\end{abstract}

Keywords: European green deal, Green agenda, environmental protection, climate change, sustainable development. 
1'orcid.org/0000-0001-8282-2777, e-mail: vasilkovzoranco@yahoo.com

2orcid.org/0000-0002-9343-5999, e-mail: slobpetrovic@yahoo.de

${ }^{3}$ orcid.org/0000-0001-7146-5612, e-mail:vukovic.jelena2@gmail.com

4orcid.org/0000-0001-6227-139X, e-mail: dragana1908@yahoo.com

${ }^{5}$ orcid.org/0000-0001-5789-4728,e-mail: adm.tfc@gmail.com

\section{UVOD / INTRODUCTION}

Evropski zeleni dogovor je nova strategija Evropske unije kao odgovor na sve veće globalne izazove i pretnje po životnu sredinu krajem druge decenije 21. veka. Njenim donošenjem od strane Evropske komisije decembra 2019. godine, nastavlja se aktivizam i posvećenost EU kao globalnog predvodnika u zaštiti životne sredine stavljajući zdravu životnu sredinu, kontrolu klimatskih promena $i$ upotrebu čiste energije u centar svih ekonomskih delatnosti država članica. Pretnje i izvori nestabilnosti po životnu srediunu zahtevaju ubrzanu akciju, osmišljenu i efikasnu ekološku transformaciju ne samo država članica EU već i susednih država i regiona.

Cilj ovog rada je dubinska analiza $i$ istraživački pristup u sagledavanju stubova ili elemenata, smernica i standarda Zelenog dogovora EU i Zelene agende za Zapadni Balkan koji su od posebnog značaja za institucije Republike Srbije, akademsku zajednicu i civilno društvo zbog usaglašavanja i sprovođenja mera, aktivnosti i zakonskih propisa ekološke zaštite kako bi građanima Republike Srbije bila omogućena zaštita prava na zdrav život i čistu životnu sredinu.

\section{REGIONALNA I GLOBALNA DIMENZIJA EVROPSKOG ZELENOG DOGOVORA ZA ZAŠTITU ŽIVOTNE SREDINE / \\ REGIONAL AND GLOBAL DIMENSION OF THE EUROPEAN GREEN AGREEMENT FOR ENVIRONMENTAL PROTECTION}

Evropski Zeleni dogovor (eng. European Green Deal) je strategijski dokument Evropske komisije (u daljem tekstu: Komisija) kojom se definiše buduća politika Evropske unije (u daljem tekstu: EU) za suočavanje sa izazovima zaštite životne sredine u uslovima klimatskih promena. Sa kolikim izazovom se suočava život ljudi i cela naša planeta ukazuju istraživanja u kojima je u poslednjih 20 godina registrovano 18 najtoplijih godina od početka merenja temperature. Ako se nastavi rast od samo $0,2^{\circ} \mathrm{C}$ po deceniji, godišnja šteta od rečnih poplava u Evropi bi bila povećana sa 5 na 112 milijardi EUR, a 16\% sredozemne klimatske zone do kraja veka bi moglo postati sušno i neproduktivno. Klimatske promene, gubitak biloške raznovrsnosti i poplavljenost obalnih područja mogle bi do 2050. prisiliti više od 140 miliona ljudi na unutrašnje migracije u Africi, južnoj Aziji i Latinskoj Americi (European Commission, COM/2020/493).

Opšti cilj Zelenog dogovora je preobražaj EU u pravedno i prosperitetno društvo sa modernom, resursno efikasnom i konkurentnom ekonomijom u kojoj 2050. neće biti neto emisije gasova staklene baste i u kom privredni rast neće biti povezan i uslovljen upotrebom ekoloških resursa. Te promene treba da zaštite, očuvaju i povećaju prirodne vrednosti uz zaštitu zdravlja i dobrobiti ljudi od rizika povezanih sa životnom sredinom i uticaja životne sredine na njih. Realizacija Zelenog dogovora je uslovljena prilagođavanjem, povezivanjem i delovanjem svih sektorskih politika na nivou Unije kako bi se na sveobuhvatan način uticalo na povećanje koristi za zdravlje, kvalitet života, otpornost i konkurentnost. Zeleni dogovor je deo strategije EU za sprovođenje Programa Ujedinjenih nacija do 2030. i ciljeva održviog razvoja (UN General Assembly A/RES/70/1, 2015). Ostvarivanje ciljeva Zelenog dogovora je nemoguće samostalnim delovanjem EU i njenih država članica jer su pitanja zaštite životne sredine, klimatskih promena i gubitka biološke raznovrsnosti globalni i zahtevaju zajednički odgovor na regionalnom i globalnom nivou. $U$ tom smislu EU namerava da koristi svoj uticaj, stručnost i finansijska sredstva kako bi pridobila susedne država i države partnere za prihvatanje smernica i standarda ekološke zaštite i podstakla aktivnije zajedničko delovanje ka ostvarivanju ciljeva strategije (European Commission, COM/2019/640).

\section{STUBOVI - ELEMENTI ZELENOG DOGOVORA EU / PILLARS - ELEMENTS OF THE EU GREEN AGREEMENT}

Poseban doprinos analize i istraživanja elemenata i smernica Zelenog dogovora se ogleda u lociranju budućih standarda ekološke žaštite do 2050 . godine od kojih će u mnogome zavisiti regionalni i globalni pravci razvoja privrede i društava, a koji treba da omoguće veći stepen zaštite zdravlja ljudi, uticaj na klimatske promene, očuvanja životne sredine, obnavljanja prirodnih ekositema i održivu upotrebu resursa. 


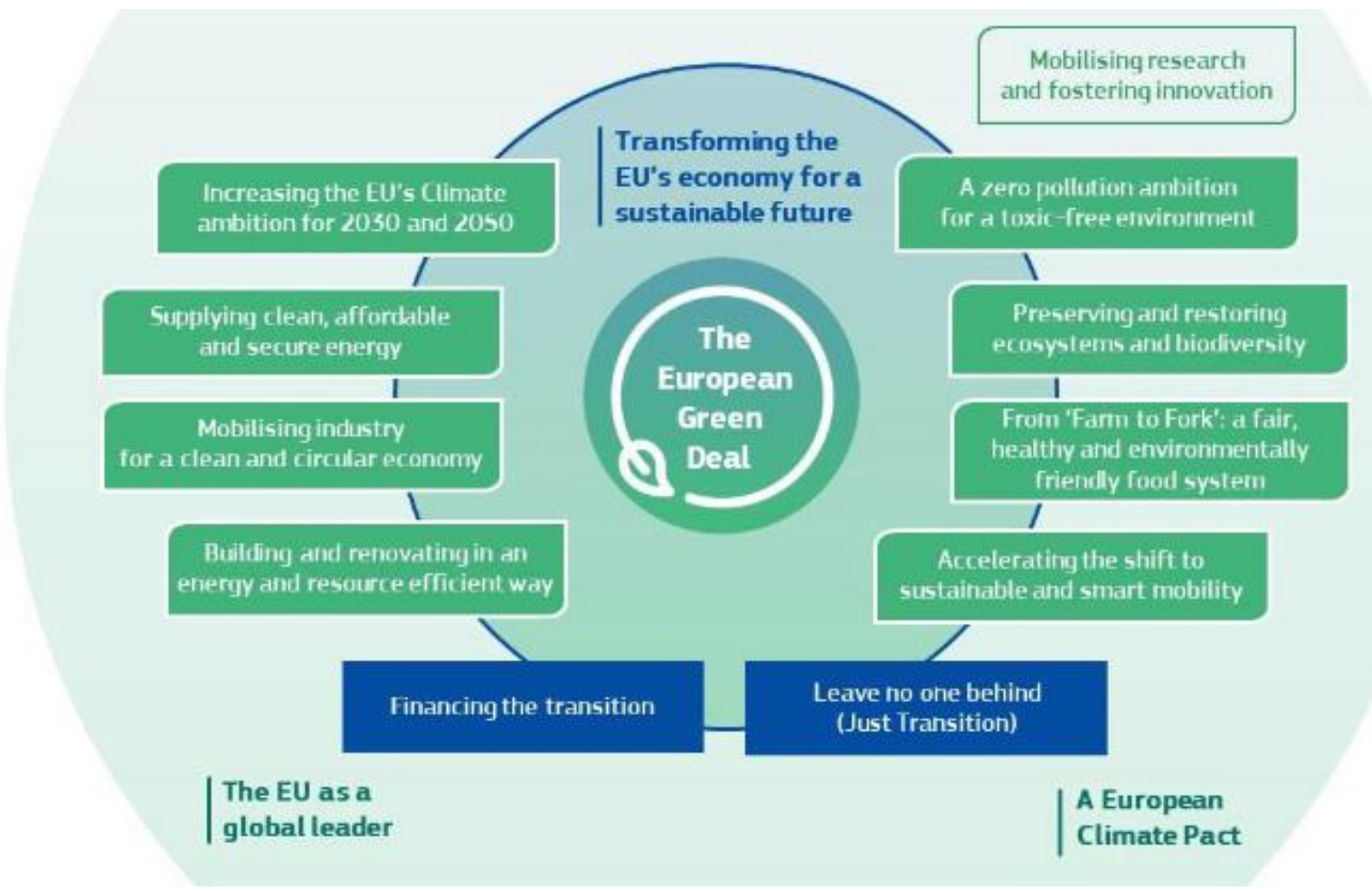

Slika 1. Evropski Zeleni dogovor

Figure 1. European Green Agreement

Izvor / Source: Evropska komisija, COM (2019) 640

Prvi stub na koji je postavljen Zeleni dogovor se odnosi na veće klimatske ambicije EU za period od 2030. do 2050. godine. U odnosu na Program Ujedinjenih nacija do 2030. i ciljeva održviog razvoja Zeleni dogovor predviđa promenu politika država članica EU i postizanje klimatske neutralnosti kontinenta do 2050. Ovaj element obuhvata međunarodnu inicijativu, promenu zakonodavstva Unije i država članica i veće promene u privredi radi izgradnje standarda za smanjenje klimatskih promena. Konkretno, postizanje klimatske neutralnosti je predviđeno sprovođenjem posebne Strategije smanjenja emisija gasova koji izazivaju efekat staklene bašte koja je dostavljena Okvirnoj konvenciji UN o klimatskim promenama (Croatia and the European Commission, 2020), izmenom Uredbe o postizanju klimatske neutralnosti (European Commission, COM/2020/80) i aktivnim delovanjem na transformaciju privrede radi smanjenja emisije staklenih gasova. Transformacija privrede EU je uveliko u toku i emisija staklenih gasova je smanjena za $23 \%$ u periodu od 1990 . do 2018. dok je privreda $u$ istom periodu zabeležila porast od $61 \%$. Ovaj tempo ipak nije dovoljan za postizanje klimatske neutralnosti jer će omogućiti smanjenje gasova sltaklene bašte za ,samo" $60 \%$ do 2050. godine. Kako bi se postigla klimatska neutralnost, Zelenim dogovorom se pomeraju rokovi i projektuje smanjenje emisije gasova za $55 \%$ odnosno
$60 \%$ do 2030 . u odnosu na 1990 . godinu. To zahteva dodatno značajno smanjenje emisije koje se namerava postići preispitivanjem i izmenom svih relevantnih instrumenata politike klimatskih promena uključujući: sistem za trgovinu emisijskim jedinicama, smanjenje emisija u državama članicama u sektorima koji nisu uključeni u sistem trgovine emisijskim jedinicama i izmenu Uredbe o korišćenju zemljišta, prenameni zemljišta i šumarstva (European Commission, COM/2019/640).

Drugi stub - element Zelenog dogovora je snabdevanje čistom i sigurnom energijom po povoljnoj ceni. Čista i sigurna energija zavisi od dekarbonizacije energetskog sektora koja je označena kao ključna aktivnost za dostizanje cilljeva u oblasti klimatskih promena u periodu od 2030. do 2050 . godine. $75 \%$ emisija staklenih gasova u EU je rezultat proizvodnje i upotrebe energije u privredi. Energetska efikasnost predstavlja prioritet, a energetski sektor se mora razvijati na obnovljivim izvorima pre svega energije vetra uz brzo i postepeno ukidanje upotrebe uglja i dekarbonizaciju gasova. Od ovog procesa dobrobit moraju da imaju potrošači i privreda. Prilikom tranzicije na snabdevanje obnovljivom energijom neophodno je sprečiti energetsko siromaštvo odnosno osigurati osnovni životni standard domačinstvima koja ne mogu da obezbede prelazak na snabdevanje obnovljivom energijom. 
Treći stub strategije se odnosi na mobilizaciju industrije za čistu cirkularnu (kružnu) privredu. Uspostavljanje i funkcionisanje klimatski neutralne cirkularne privrede usko je povezano sa transformacijom industrijskog sektora i svih lanaca snabdevanja. Globalna eksploatacija resursa i prerada u materijale, goriva, i hranu proizvodi $50 \%$ emisije gasova staklene bašte i utiče na gubitak više od $90 \%$ biološke raznovrsnosti i nestašicu vode. I pored započetih promena industrija EU emituje 20\% globalne emisije gasova staklene bašte i samo $12 \%$ materijala koji se u njoj upotrebljavaju dolazi iz recikliranja. Energetski intenzivne industrije kao što su industrija čelika, hemikalija i cementa koje su veoma važne za privrede država članica EU moraju biti kao i energetski sektor podvrgnute intenzivnoj dekarbonizaciji. Planira se uvođenje napredne tehnologije proizvodnje čistog čelika sa nultim emisijama ugljendioksida do 2030. Predviđeno je stavljanje posebnog akcenta na upotrebu tehnologije sa niskom emisijom gasova, dalji razvoj cirkularne ekonomije na osnovu novog akcionog plana za ovu oblast koji sadrži mere za modernizaciju privrede EU koja treba da omogući razvoj tržišta za klimatski neutralne i cirkularne proizvode. Delovanje će posebno biti usmereno na tzv. resursno intenzivne sektore kao što su tekstilni sektor, građevinarstvo i sektor elektronike i plastike. Ne manje važne su mere koje će podsticati preduzeća da nude i omogućavaju potrošačima da odaberu trajne i popravljive proizvode koji se mogu ponovno upotrebljavati posebno elektronskih uređeja. Tako se smanjuje otpad i smanjuje njegov uticaj na životnu sredinu i klimatske promene. I $z$ tog razloga je neophodno unapređenje upravljanja otpadom, razvoj modela za odvojeno prikupljanje otpada kao i podsticanje tržišta sekundarnih sirovina sa obaveznim procentom za reciklažu kao što su ambalaža, vozila, građevinski materiali i baterije.

Četvrti stub je izgradnja i obnova uz efikasnu upotrebu energije i resursa. Odnosi se na građevinarstvo, odnosno izgradnju, upotrebu i renoviranje zgrada što zahteva značajne količine energije i mineralnih resursa. Energetska efikasnost u izgradnji i obnovi zgrada je bitna kako bi se smanjio procenat energije koji odlazi na zagrevanje domova, a procene ukazuju da oko 50 miliona potrošača u EU ima problema sa zagrevanjem svojih domova. Predviđeno je povećanje stope renoviranja javnih i privatnih zgrada i time smanjivanje rasipanja energije uz striktno sprovođenje zakonodavstava koje se odnosi na energetska svojstva zgrada. Podsitču se javno-privatna partnerstva i inicira korišćenje platforme namenjene za sektor stanogradnje i građevinarstva gde će biti uključeni arhitekte i inženjeri koji bi sa lokalnim vlastima otklonili prepreke za obnovu zgrada i uticali na smanjenje troškova.
Brži prelazak na održivu i pametnu mobilnost je peti stub Zelenog dogovora. U njegovoj osnovi se nalazi saobraćaj koji proizvodi $25 \%$ ukupnih emisija gasova staklene baste u EU a za dostizanje klimatske neutralnosti do 2050. godine, procenjuje se da emisije koje proizvodi saobraćaj treba smanjiti za $90 \%$. Tom smanjenju treba doprineti putni, železnički, avionski i vodeni saobraćaj, na način da se korisnicima stave na raspolaganje pristupačnije, dostupnuje, zdravije i čistije alternative saobraćaja. Smatra se da bi jedno od rešenja bilo prebacivanje $75 \%$ ukupnog kopnenog putnog transporta na prevoz železnicom i unutrašnjim plovnim putevima. $U$ tom pravcu je neophodna izmena zakonodavstva i povlaćenje već podnetog predloga o izmeni Direktive o kombinovanom prevozu (European Commission, $\mathrm{COM} / 2017 / 648)$. Pametne sisteme upravljanja saobraćajem zajedno sa automatizovanom i povezanom multimodalnom mobilnošću treba uvesti uz pomoć digitalizacije celokupnog saobraćajnog sistema i infrastrukture. Oni će značajno doprineti smanjenju zagađenja i zagušenja, posebno u gradskim područjima. Gradovi zahtevaju hitno delovanje i primenu različitih mera za smanjenje emisija, zagađenja, zagušenja i unapređenja gradskog prevoza. $U$ tom smislu predviđene su izmene zakonodavnog okvira o standardnim vrednostima emisija $\mathrm{CO}_{2}$ za automobile kako bi se pripremili korisnici za mobilnost sa nultom stopom emisija od 2025. godine. Ove mere će biti praćene povećanjem proizvodnje i upotrebom održivih alternativnih goriva u saobraćaju, kao i izmenom Direktive o infrastrukturi za alternativna goriva (EU Directive, 2014/94) kako bi se ubrzalo uvođenje vozila i plovila sa nultim i niskim emisijama gasova.

Strategija od „polja do stola” odnosno uspostavljanje zdravog prehrambenog sektora koji je prihvatljiv za životnu sredinu je sledeći element Zelenog dogovora koji kao posebna strategija treba da doprinese sveobuhvatnom povezivanju poljoprivredne proizvodnje odnosno proizvodnje hrane sa ekološkom zaštitom. Proizvodnja hrane prouzrokuje zagađenje vazduha vode i zemljišta, gubitak biološke raznovrsnosti i pospešuje klimatske promene zbog prekomernog trošenja prirodnih resursa. Predviđene su mere smanjenja uticaja prehrambeno-prerađivačkog sektora i maloprodaje na životnu sredinu aktivnijim pristupom i regulacijom u oblastima transporta, skladištenja, pakovanja i rasipanja hrane što će zahtevati promene i ubrzanu transformaciju privrede u model cirkularne ekonomije (European Commission, COM/2019/640).

Očuvanje i obnavljanje ekosistema i biološke raznolikosti su od vitalnog značaja za život, ishranu, očuvanje vode za piće i čistog vazduha uz istovremeno ublažavanje prirodnih katastrofa, suzbijanje 
bolesti i regulaciju klime. I za ovaj element Zelenog plana je predviđeno donošenje posebne strategije čije sprovođenje treba da doprinese proširivanju zaštite kopnenih i morskih područja sa bogatom biološkom raznolikošću sa posebnim merama za države članice za unapređenje i obnavljanje oštećenih ekosistema, unapređenje zaštite životne sredine u gradovima i povećanje biološke raznolikosti u gradskim područjima. Ova strategija će uključivati i delovanje na zaštiti šumskih kompleksa i ekosistema koji su sve više ugroženi zbog klimatskih promena. Ostvarivanje klimatske neutralnosti i zaštita životne sredine je usko povezano sa delovanjem u oblasti šuma posebno u pošumljavanju koje omogućavaju apsorpciju ugljendioksida. EU u ovoj oblasti pokušava da aktivnije deluje i na međunarodnom planu posebno na zaštiti i obnovi svetskih šuma (European Commission, COM/2019/352).

Poslednji stub Zelenog dogovora se odnosi na dostizanje cilja „nulte stope zagađenja za netoksičnu životnu sredinu". Osnova stvaranja netoksične životne sredine je preventivno delovanje na sprečavanju zagađenja i uvođenje mera za čišćenje i uklanjanje zagađenja. To se pre svega odnosi na sprečavanje zagađenja osnovnih ekoloških vrednosti kao što su voda, vazdun i zemljište. Obnova prirodnih funkcija podzemnih i površinskih voda je neophodno za očuvanje i obnovu biološkog diverziteta jezera, reka, močvara i ušća kao i za smanjenje šteta od poplava. Predviđene su mere za rešavanje problema zagađenja od oticanja gradskih voda do posebno štetnih izvora zagađenja kao što su mikroplastika i hemikalije, uključujući farmaceutske proizvode. Komisija će morati u narednom periodu predložiti izmene zakonodavstva i reviziju standarda kvlaiteta vazduha i modele za rešavanje problema zagađenja iz velikih industrijskih postrojenja. Izmene i primenu propisa, mera i standarda usmerene na sprečavanja zagađenja neophodno je uskladiti sa politikama u oblasti klimatskih promena, energije i cirkularne ekonomije.

\section{ZELENA AGENDA ZA ZAPADNI BALKAN / GREEN AGENDA FOR THE WESTERN BALKANS}

Zelena agenda za Zapadni Balkan (u daljem tekstu: ZB) obuhvata smernice Komisije predstavljene kao radni dokument (European Commission, SWD/2020/223) u okviru Ekonomskog i investicionog plana za ZB (European Commission, COM(2020) 641). Zasnovan na predpristupnim fondovima ovaj plan predviđa uključivanje ekoloških ciljeva iz Zelenog dogovora EU u sve aktivnosti za ekonomski oporavak $\mathrm{i}$ investicioni ciklus za region do 2027. godine. Zelena agenda za ZB je u obliku deklaracije prihvaćena od strane šefova država i vlada država ZB na samitu Zapadni Balkan - EU (u okviru Berlinskog procesa), održanog u Sofiji, 10.11.2020. godine (Deklaracija, 2020).

Zelena agenda je nacrt mogućih mera koje moraju biti usvojene na osnovu postojećih sporazuma o stabilizaciji i pridruživanju, u okviru pregovaračkih poglavlja za pristupanje EU i programima ekonomske saradnje. Ovaj dokument, suštinski predstavlja listu smernica, prioriteta i ciljeva koje treba dostići u oblastima: (1) dekarbonizacije unutar klime, energetike i mobilnosti, (2) cirkularne ekonomije sa posebnim akcentom na otpad, recikliranje, održivu proizvodnju i efikasno korišćenje resursa, (3) zaštite i obnove biodiverziteta, (4) borbe protiv zagađenja vazduha, vode i zemljišta i (5) održive poljoprivrede, prehrambene proizvodnje i ruralnih oblasti.

Sve mere države ZB moraju preduzeti na nacionalnom nivou uz obavezu uspostavljanja okvira za regionalnu i međunarodnu saradnju kao i usklađivanja sa zakonodavstvom, pravnim tekovinama i standardima EU u vezi ekološke zaštite i prioritetima predviđenim u Zelenom dogovoru EU.

1) Dekarbonizacija predviđena Zelenom agendom obuhvata klimu, energetiku i mobilnost. Zapadni Balkan je prepoznat kao jedan od regiona u Evropi koji je najviše pogođen klimatskim promenama sa procenama porasta temperature u budućnosti od 1,7 - $4,0^{\circ} \mathrm{C}$, pa čak i preko $5,0^{\circ} \mathrm{C}$ do kraja veka, u zavisnosti od globalnih napora u smanjenju emisije gasova sa efektom staklene bašte. Prosečni rast temperature u skladu sa Pariskim sporazumom o klimatskim promenama treba biti ispod $2^{\circ} \mathrm{C}$, a klimatska neutralnost do 2050. godine predviđena Zakonom (Uredbom) o klimatskim promenama EU je sastavni deo strategije za ZB i uticaće na bilateralne odnose EU i države ZB kao i na pregovore o pristupanju država ZB Evropskoj uniji. U tom smislu novousvojeni Zakon o klimatskim promenama Republike Srbije je dobar iskorak u pravcu ispunjavanja obaveza prihvaćenih pristupanjem Pariskom sporazumu kao i usklađivanja sa zakonodavstvom EU (Zakon o klimatskim promenama, 2021). U Zelenoj agendi za ZB se radi postizanja zajedničkog cilja od strane EU nudi iskustvo, znanje i resursi kako bi se podstakla i poboljšala otpornost regiona u prilagođavanju neizbežnim uticajima klimatskih promena. Stoga je neophodno za sve sektorske politike u državama ZB planirati određivanje i ostvarivanje ciljeva u oblasti energetike i klimatskih promena do 2030. godine.

Dekarbonizaciju ili oslobađanje od ugljenika u energetskom sektoru je predviđeno podsticanjem i prihvatanjem šeme EU za trgovanje emisijama kao i usvajanjem instrumenta za određivanje cene ugljenika. To je moguće ostvariti integrisanim nacionalnim energetskim i klimatskim planovima sa konkretnim i ostvarljivim merama za smanjenje emisije gasova 
sa efektom staklene bašte u ekonomijama ZB. U njima bi trebalo predvideti upotrebu naprednih tehnologija u sprečavanju klimatskih promena i postizanju klimatske neutralnosti (Mentus, Jovanović, 2020). Posebno je zanačajno preispitati i izmeniti zakonsku regulativu za sektor energetike kako bi se unapredio zakonodavni okvir za ubrzavanje procesa dekarbonizacije. To obuhvata smanjivanje i postepeno ukidanje subvencija za ugalj uz striktno poštovanje pravila o državnoj pomoći.

Energetska efikasnost je preduslov za postizanje dekarbonizacije uz najniže moguće troškove. Ona se mora poboljšati i unaprediti u svim sektorima kao i uključiti u budućim investicijama povezanim sa energetikom.

Udeo energije iz obnovljivih izvora je neophodno povećati u odnosu na dostignuti nivo i obezbediti uslove za investicije u oblasti obnovljivih izvora energije. Prelazak na obnovljive izvore energije u perspektivi treba povezati sa socijalnom dimenzijom koja se može manifestovati u energetsko siromaštvo. Ublažavanje i rešavanje problema energetskog siromaštva se može postići uspostavljanjem povoljnih finansijskih podsticaja (šema) za obnovu domaćinstava i za ugrožene kategorije socijalnim izdvajanjima za obezbeđenje osnovnog životnog standarda.

Građevinski sektor se spominje u Zelenoj agendi kao jedno od ključnih područja u kojem bi se mogle ostvariti najveće uštede energije. $U$ tom smislu osim izgradnje bi trebalo uz obezbeđivnaje adekvatnog finansiranja, unaprediti i podržati obnovu privatnih stambenih $\mathrm{i}$ javnih zgrada.

Pametna i održiva mobilnost u okviru Zelene agende za ZB se odnosi na transport, transportne mreže, promene načina prevoza radi smanjenja emisije ugljendioksida i upotrebe čistijih goriva. Napominje se da su drumske, železničke veze i veze unutrašnjih vodenih puteva u regionu nerazivjene zbog nedovoljnih investicija i lošeg održavanja. Predlaže se preispitivanje transportnih strategija $i$ promovisanje zelene i održive transportne mreže. $U$ okviru toga se podstiče prelazak sa drumskog na železnički transport i transport unutrašnjim vodenim putevima uz neophodno poboljšanje infrastruktire i povezivanje morskih ili rečnih luka sa železničkim mrežama. Takođe je potreban aktivniji pristup sprovođenju regionalnog akcionog plana za reforme železnica kao i definisanje koridora za železnički teretni saobraćaj i unutrašnje vodne puteve u okviru sveobuhvatne strategije za prelazak sa drumskog transporta na vidove transporta koji su pogodniji za životnu sredinu. Ne manje važno za mobilnost je prihvatanje i sprovođenje tehničkih standarda EU i uvođenje digitalizacije za sve vidove transporta. Uz ove mere potrebno je usvajanje i sprovođenje planova za klimatsku otpornost transportnih mreža ZB kao i planova održive urbane mobilnosti za gradska područja.

2) Cirkularna ekonomija - Cirkularna (kružna) ekonomija je model ekonomije u kojoj se vrednost i resursi održavaju, odnosno kruže u što je moguće dužem vremenskom periodu uz minimalno stvaranje otpada sa smanjenim pritiskom na prirodne resurse i podsticajem održivog rasta i otvaranjem novih radnih mesta. Cirkularna ekonomija obuhvata rešavanje ukupnog životnog ciklusa proizvoda, od dizajna i proizvodnje do potrošnje, popravke, ponovne upotrebe, recikliranja i vraćanja resursa u ekonomiju. Cirkularni model se oslanja na obnovljive izvore energije i u tom kontekstu gradi ekonomski, prirodni i društveni kapital (Golubović-Stojanović, Brnjas, 2020). Trenutne procene Komisije su da se proces prelaska sa linearne na cirkularnu ekonomiju u državama ZB odvija sporo. Ovaj proces zahteva dodatne napore i finansijska sredstva za pravednu tranziciju kako bi se doprinelo zaštiti životne sredine između ostalog značajnim minimiziranjem količine proizvedenog otpada u regionu. Obezbeđivanje održivog snabdevanja sirovinama, posebno kritičnim sirovinama širenjem ponude iz primarnih i sekundarnih izvora jedan je od preduslova za prelazak na cirkularnu ekonomiju. Donošenje i sprovođenje nacionalnih strategija cirkularne ekonomije po modelu strategije i akcionog plana EU za cirkularnu ekonomiju bi omogućilo dodatno približavanje privreda država ZB jedinstvenom tržištu Unije (European Commission $\mathrm{COM} / 2020 / 98)$. U strategijama bi trebalo staviti akcenat na sagledavanje celog životnog ciklusa proizvoda, prevenciju otpada, savremenom upravljanju otpadom i reciklaži, ponovnoj upotrebi i popravki proizvoda kao i na ponovnoj proizvodnji. Neophodno je posvetiti posebnu pažnju recikliranju koje je u državama ZB zastupljeno sa $3 \%$ u odnosu na $44 \%$ unutar EU. Jedna od mera za povećanje procenta reciklaže je primena šeme odvojenog sakupljanja otpada, pre svega odvajanjem papira, metala, plastike, stakla i biootpada. Za to je potrebno dodatno unaprediti infrastrukturu za upravljanje otpadom u gradovima i regionima.

3) Smanjenje zagađenja vazduha, vode i zemljišta je od vitalnog značaja za zdravlje ljudi. Zagađenje vazduha u regionu i dalje je jedno od najviših u Evropi. Zagađenje vazduha je posledica zagađenja praškastim materijama koje dolaze iz emisija, iz industrijskih postrojenja (termoelektrane na ugalj), kučnog grejanja (peći i kotlovi na drva i ugalj, kao i sagorevanja otpada u domaćinstvima) i saobraćaja (stara vozila). Kako bi se ovo stanje promenilo potrebno je obezbediti primenu zakonskih normi o 
kvalitetu vazduha, uspostavljanje sistema za praćenje kvaliteta vazduha, uključujući akreditaciju mreža za praćenje kvaliteta vazduha, kao i uspostavljanje i izveštavanje o registrima emisija i projekcijama emisija. Usvajanje i sprovođenje strategija o kvalitetu vazduha bi pomogle da se definišu i primene najbolje mere za smenjenje zagađenja vazduha. Strategija o zaštiti vazduha je osnovni dokument na osnovu koga se donose planovi kvaliteta vazduha, kratkoročni akcioni planovi i programi za smanjenje emisija zagađujućih materijala u vazduhu (Koalicija 27, 2020). Ta strategija na primer, i pored obaveze iz Zakona za zaštitu vazduha u Republici Srbiji još uvek nije usvojena (Zakon o zaštiti vazduha, 2009 i 2013).



Slika 2. Modelirana godišnja srednja vrednost koncentracija PM 2,5 u regionu ZB, 2016 Figure 2. Modeled annual mean value of PM 2.5 concentrations in the WB region, 2016 Izvor / Source: SWD(2020) 223

Posebne izazove u zaštiti voda predstavljaju pritisci na količinu crpljene vode za industriju, poljoprivredu i javno vodosnabdevanje, povećanje hidroenergetskog kapacitita sa negativnim uticajem na životnu sredinu $\mathrm{i}$ ispuštanje neprečišćenih otpadnih voda. Izuzetno mali procenat prerade otpadnih voda predstavlja možda i najveći izazov u oblasti zaštite životne sredine kako u Srbiji tako i ostalim zemljama ZB pre svega zbog finansijskih sredstava za izradu sistema za prečišćavanje u regionu. Suočavanje sa ovim izazovima zahteva hitno unapređenje i osavremenjivanje infrastrukture za praćenje voda kao i izgradnja neophodne infrastrukture za tretman otpadnih voda.

Zaštita zemljišta se pre svega odnosi na borbu protiv degradacije zemljišta i obnavljanje degradiranog zemljišta koja uključuje održivu proizvodnju hrane, održivo upravljanje šumama, upravljanje organskim ugljenikom u zemljištu, očuvanje ekosistema i smanjenje krčenja šuma. Zaštitu zemljišta je neophodno integrisati u druge oblasti i politike i kroz uspostavljanje regionalnog partnerstva za zemljište poboljšati razmenu znanja i utvrditi i primeniti primere najbolje prakse za zaštitu zemljišta od zagađenja i degradacije.

4) Održiva poljoprivredna i prehrambena proizvodnja. Udeo poljoprivrede i povezanih sektora $u$ državama ZB je oko $10 \%$ bruto domaćeg proizvoda, dok je udeo poljoprivrede, šumarstva i ribarstva oko $20 \%$ ukupne radne snage. Transformaciju poljoprivrednog sektora treba usmeriti ka minimiziranju njegovog negativnog uticaja na životnu sredinu i klimu. Potrebno je usmeriti delovanje na zaštiti pristupačne i zdrave hrane za građane i izvozna tržišta, i to:

- poljoprivredno-prehrambeni sektor i sektor primarne proizvodnje uskladiti sa standardima EU za bezbednost hrane, zdravlje biljaka i životinja i dobrobit zaštite životne sredine, uz aktivnosti usmerene na upravljanje otpadnim vodama, stajskim đubrivom i otpadom,

- $\quad$ radi obezbeđivanja bezbednosti hrane, ojačati sanitarnu kontrolu u celom prehrambenom lancu 
i poboljšati praćenje i obeležavanje prehrambenih proizvoda (uključujući usklađeni elektronski sistem sertifikacije),

- unapređivati i podsticati poljoprivrednu proizvodnju koja je u skladu sa životnom sredinom i organsku poljoprivrednu proizvodnju. Istovremeno, podsticati smanjenje sintetičkih hemijskih proizvoda koji se koriste u proizvodnji hrane kao što su pesticidi, veterinarski proizvodi i đubriva,

- delovati u pravcu smanjivanja otpada u ruralnim i priobalnim oblastima (duž puteva, u seoskim rekama),

- usmeravati i podržati investicije u proizvodnju obnovljive energije i tehnologije, kao i smanjenje emisija i mere za prilagođavanje klimatskim promenama u poljoprivredi.

5) Biodiverzitet i priroda su sa jedne strane, izvori hrane, sveže vode i čistog vazduha dok sa druge strane, omogućavaju zaštitu od poplava, ublažavaju prirodne katastrofe, doprinose regulisanju klime i doprinose borbi protiv degradacije zemljišta. Zbog toga je za države ZB neophodno definisanje okvira za biodiverzitet posle 2020 . godine. $U$ tome značajnu ulogu ima uključivanje država regiona sa određenim listama staništa, retkih životinja i ptica i zaštićenih bioloških vrsta u mrežu Natura 2000. Do sada je u Srbiji registrovano 89 tipova staništa, 150 životinjskih vrsta kao i 116 vrsta ptica po klasifikacijama iz zakonodavstva EU o zaštiti prirode i biodiverziteta (Zaštita životne sredine - saradnja EU i Srbije, 2021). Razvoj dugoročne politike za zaustavljanje gubitka biodiverziteta, zaštitu i obnavljanje ekosistema bi u regionu trebalo postići kroz:

- usvajanje i sprovođenje Strateškog plana za biodiverzitet do 2030. godine i planiranje sredstva za zajedničko sprovođenje, praćenje i izveštavanje u vezi ovog plana;

- donošenje i sprovođenje planova zaštite i obnavljanja prirode uključujući primorska područja;

- usvajanje i sprovođenje planova obnove šumskih predela na nacionalnom nivou i za ceo region,

- unapeđivanje razmene znanja, uključujući prikupljanje, upravljanje i raspolaganje informacijama o biodiverzitetu i očuvanju prirode, kao i razvijanja partnerstva između istraživačkih centara i postojećih platformi ZB i EU, uz istraživanje mogućnosti za uspostavljanje Informativnog centra za biodiverzitet država ZB.

\section{ZAKLJUČAK / CONCLUSION}

Zeleni dogovor EU i Zelena agenda za ZB su dve nove strategije EU u kojima se potencira zaštita životne sredine i borba protiv klimatskih promena. One su pregled stanja rizika i pretnji po životnu sredinu sa jasnim smernicama budućeg delovanja država u promeni politika, izmeni zakonodavstava i jačanja svesti pojedinaca sa primerenijim i ubrzanijim vremenskim okvirom mera za zaštitu osnovnih ekoloških vrednosti u zemljama EU i ZB. Predstavljaju regionalni odgovor globalnog problema današnjice koji se bazira na rezultatima naučnih istraživanja u oblastima: klime, biološkog diverziteta, stanja vode, vazduha i zemljišta. Detaljna analiza i istraživanje ovih strategija u ovom radu pokazuju da su standardi i aktivnosti za zaštitu životne sredine od ključne važnosti za sve odblasti održivog društvenoekonomskog razvoja, sa izgrađenim projekcijama i interdisciplinarnim elementima koje treba primeniti kako bi se ostvarilo parvo svakog građina na zdrav život u zdravoj i čistoj zivotnoj sredini. Neophodnosti snažnije ekološke zaštite, postizanje klimatske neutralnosti, upotreba obnovljivih energija, briga 0 kvalitetu vode, vazduha i zemljišta, zaštita prirode, životinjskih vrsta i staništa zahtevaju posvećenost i sposobnost za donošenje teških odluka, kao i opšti društveni konsenzus građana, civilnog društva i nacionalnih institucija za delovanje ka zajedničkom dobru čovečanstva. Aktivniji pristup međunarodne zajednice u okviru Ujedinjenih nacija, Evropske unije i ostalih regionalnih organizacija za očuvanje prirode i životne sredine mora biti samo potrebna i značajna nadogradnja delovanju Republike Srbije i država Zapadnog Balkana zajedno sa državama članicama EU u sprečavanju budućih ekoloških katastrofa, pandemija i kriza koje proizlaze iz prekomerne eksploatacije, menjanja i uništavanja prirode u trci za materijalnim dobrima i visokim nacionalnim dohotkom, kao i nemarnog i indolentnog odnosa ljudi prema prirodi i životnoj okolini.

\section{LITERATURA / REFERENCES}

[1] Commission Staff Working Document - Guidelines for the Implementation of the Green Agenda for the Western Balkans Accompanying the Communication from the Commission to the European Parliament, the Council, the European Economic and Social Committee and the Committee of the Regions An Economic and Investment Plan for the Western Balkans, SWD(2020)223 final, Brussels, 6.10.2020. Prevod na srpski na: http://www.pregovarackagrupa27.gov.rs/dostupn i-prevodi-dokumenata/. Pristup 06.04.2021

[2] Communication from the Commission to the European Parliament and the Council 2020 Strategic Foresight Report Strategic Foresight - Charting The Course Towards A More Resilient Europe, COM(2020) 493 final, Brussels, 9.9.2020, 1- 43.

[3] Communication from the Commission to the European Parliament, the European Council, the Co- 
uncil, the European Economic and Social Committee and the Committee of the Regions - The European Green Deal, COM(2019) 640 final, Brussels, 11.12.2019, 1- 24.

[4] Communication from the Commission to the European Parliament, the European Council, the Council, the European Economic and Social Committee and the Committee of the Regions - Stepping up EU Action to Protect and Restore the World's Forests, COM(2019) 352 final, Brussels, 23.7. 2019.

[5] Communication from the Commission to the European Parliament, the European Council, the Council, the European Economic and Social Committee and the Committee of the Regions - An Economic and Investment Plan for the Western Balkans, COM(2020) 641 final, Brussels, 6.10. 2020. Prevod na srpski na:

http://www.pregovarackagrupa27.gov.rs/dostupn i-prevodi-dokumenata/. Pristup 07.04.2021.

[6] Communication from the Commission to the European Parliament, the European Council, the Council, the European Economic and Social Committee and the Committee of the Regions - $A$ new Circular Economy Action Plan for a cleaner and more competitive Europe, COM(2020) 98 final Brussels, 11.3.2020.

[7] Deklaracija iz Sofije o Zelenoj agendi za Zapadni Balkan, http://www.pregovarackagrupa27.gov.rs/?wpfb_ $\mathrm{dl}=173$. Pristup 07.04.2021.

[8] Directive 2014/94/EU of the European Parliament and of the Council of 22 October 2014 on the deployment of alternative fuels infrastructure Text with EEA relevance, OJ L 307, 28.10.2014.

[9] Golubović-Stojanović, A., Brnjas, Z., (2020). Savremeni koncepti globalnog održivog razvoja i „cirkularna ekonomija“, Ecologica, 27(99), 507512.

[10] Koalicija 27 - Alternativa za bezbednije hemikalije, Beogradska otvorena škola et al., (2020). Pog- lavlje 27 u Srbiji: Napredak u magli, Alta Nova, Beograd,

https://rs.boell.org/sites/default/files/2020-

10/izvestaj-2020.pdf. Pristup 08.04.2021.

[11] Mentus, S., Jovanović, L., (2020). Napredne tehnologije u sprečavanju klimatskih promena, Ecologica, 27(100), 579-588.

[12] Proposal for a Directive of the European Parliament and of the Council amending Directive 92/106/EEC on the establishment of common rules for certain types of combined transport of goods between Member States, COM(2017) 648 final, 2017/0290 (COD), Brussels, 8.11.2017.

[13] Proposal for a Regulation of the European Parliament and of the Council establishing the framework for achieving climate neutrality and amending Regulation (EU) 2018/1999 (European Climate Law), COM(2020) 80 final, 2020/0036 (COD), Brussels, 4.3.2020.

[14] Submission by Croatia and the European Commission on behalf of the European Union and its Member States, Subject: Long-term low greenhouse gas emission development strategy of the European Union and its Member States, Zagreb, 6 March 2020, https://unfccc.int/sites/default/ files/resource/HR-03-06-2020\%20EU\%20 Submission\%20on\%20Long\%20term\%20strateg y.pdf. Pristup 03.04.2021.

[15] UN General Assembly, 2015, Transforming our world: the 2030 Agenda for Sustainable Development, Resolution adopted by the UN General Assembly on 25 September 2015, A/RES/70/1, https://www.un.org/ga/search/view_doc.asp?sy $\mathrm{mbol}=\mathrm{A} / \mathrm{RES} / 70 / 1$ \&Lang=E. Pristup 03.04.2021.

[16] Zakon o klimatskim promenama, Službeni glasnik RS, br. 26/2021.

[17] Zakon o zaštiti vazduha, Službeni glasnik RS, br. $36 / 2009$ i 10/2013.

[18] Zaštita životne sredine - saradnja EU i Srbije, http://europa.rs/zastita-zivotne-sredine-saradnjaeu-i-srbije/. Pristup 08.04.2021. 